\section{Schlafbezogene dissoziative Störung}

Helga Peter

Marburg, Deutschland

\section{Synonyme}

Dissoziative Störung während der Schlafepisode

\section{Englischer Begriff}

sleep related dissociative disorder

\section{Definition}

In der ICSD-2 war diese Störung unter $>$ „Parasomnien“ in der Kategorie „Andere Parasomnien“ enthalten. Für die ICSD-3 wurde die Diagnose gestrichen. 